\title{
Negative Prejudice of The Newsmaking of Veiled Women in Hate Crime Perspective
}

\author{
S B Sumbogo, M Margaret \\ Budi Luhur University, Jakarta \\ supriyono@budiluhur.ac.id, monica.margaret@budiluhur.ac.id
}

\begin{abstract}
After the Surabaya bombing incident on Sunday, May 13, 2018, news about veiled women by certain media was linked to radical movements and terrorism. Often, the news is based on one source and initial allegations, without first verifying. In fact, through news headlines or news content editors, the news implies that there is hatred or suspicion of the mass media for veiled women. Such reporting is indeed supported and strengthens negative public perceptions of veiled women. Numerous studies show that veiled women are not accepted in society. They are suspected as being members of a terrorist community or even followers of a cult. Women are often excluded or even considered by some people about their existence. News about veiled women who are associated with certain disproportionate crimes, especially those that do not fit the facts in full, can lead to misinterpretations and negative perceptions in society towards veiled women. It can even encourage the public to commit acts of violence against veiled women, both in the form of visual and verbal violence. In a criminological perspective, such newsmaking can be categorized as hate crime, which places women wearing veils as victims of mass media crimes. This study is intended to analyze the reporting of veiled women based on the perspective of hate crime. The study was conducted on media coverage over a period of 6 months, to find out whether the negative perceptions of mass media coverage of veiled women were consistent or changes occurred.
\end{abstract}

Keywords: Veiled women, terrorism, negative prejudice

\section{INTRODUCTION}

News not only displays factual information that is neutral, but also wants to convey certain messages that are hidden (implicit) or explicit. The message can be in the form of a partisanship of journalists or press agencies to a group, followers of religion, race, values, norms, isms, beliefs, and others. Even in the context of crime events, Greek Barack (2009) found a tendency for the mass media to do mystification (obscurity of meaning), so it is not in accordance with reality. Regarding the crime, according to Barack, the mass media coverage tends to create a "new reality" about crime that is not in accordance with reality, so as to cause certain interpretations and views among readers/audiences for the crime, both against the perpetrators and victims of crime.

After the suicide bombing at a church in Surabaya, East Java, on Sunday, May 13, 2018 , the mass media coverage of veiled women was not in accordance with reality. The mass media tends to link the use of the veil with radical movements and terrorism. As a result, the community and police are cautious and suspicious of veiled women. The suicide bombing that 
occurred in Surabaya indeed presents an astonishing new phenomenon in acts of terrorism in Indonesia. The suicide bombing was carried out by a mother with her two daughters who were woren the long dressed and veiled. All of them died instantly (www.forumkeadilan.com, 2018). The day before, on Saturday 12 May 2018, two veiled women were arrested by the police for displaying strange behavior. They allegedly planned to stab a member of Brimob at the Mobile Brigade (Brimob) Command Headquarters, Kelapa Dua, Depok (www.tribun.co.id, 2018).

After the two events above, the news about veiled women by certain media was associated with the radical movements and terrorism. Often the news is based on one source and initial allegations, without first verifying. In fact, through headlines news or news content editors, the news implies that there is hatred or suspicion of the mass media for veiled women. In a criminological perspective, such reporting can be categorized as hate crime, which places women wearing veils as victims of mass media crimes.

For example, the preaching of a parade of kindergarten students who were veiled and carrying a replica of a long-barreled weapon on August 17, 2018 in Probolinggo, Central Java, was directly linked to the spread of radicalism and acts of terrorism by the mass media. The $\mathrm{BBC}$ Indonesia website, for example, makes the title "Parades of kindergarten students wearing veils and carrying replicas of weapons, a sign that the threat of radicalism is taking root". (www.bbc.com/indonesia, 2018). The parade that was videotaped and distributed through social media was then responded with suspicion by various parties. Commissioner of the Indonesian Child Protection Commission (KPAI) Siti Hikmawati, demanded that the police investigate further and give strict sanctions to the school which was considered to have exposed children to the veil attributes and weapons replicas that are usually attached to radical groups - in carnival activities. (www.bbc.com/indonesia, 2018).

News like this is more prominent in online-based media. This is because online media prioritizes the speed of writing and disseminating news, thus ignoring further verification and search processes. The reporting of crime events in the mass media actually aims to carry out the crime control function. According to MacQuail (1992), as quoted by Barak, the first feature that can be attached to the media is the "function" (or hidden purpose) to ensure the continuity of social order, build public consensus on values, integrate activities, retain people and group in society. However, although the media has a role as an agent of social control, reporting a crime in the mass media is basically an interpretation, because journalists do not witness the event directly. As an interpretation, as a "reality" the news has been formed or constructed by its journalists, editors, and editor in chief.

News about veiled women who are associated with certain disproportionate crimes, especially those that do not fit the facts as a whole, can lead to misinterpretations and negative perceptions in society towards veiled women. It can even encourage the public to commit acts of violence against veiled women, both in the form of visual and verbal violence.

\section{Negative Prejudice of Veiled Women}

The study specifically discusses the hate crime aspect of mass media reporting on veiled women so far not yet found by the author. However, studies on people's perception about veiled women have indeed been carried out. For example, conducted by Indra Taura, who was posted in the Journal of Equilibrium FKIP Unismuh Makassar, Volume II No. January 1, 2016 titled "Community Perceptions About Veiled Women (Case Study of To'bia Village, Luwu Regency). This research found that a number of women in the village of Tobia claimed to use the veil because they follow religious teachings. For those who cover the 
genitals required or required in religion, they also assume that wearing the veil is also one way to cover the genitals, there is also a reason they use the veil because of external influences such as coercion by their own husbands and also because of the demands of organizations that make them veiled but over time they use the veil because they themselves are no longer due to coercion of others, because they also interact with other communities that make their eyes open that closing the genitals or veiling is a beautiful thing no longer an unacceptable thing to the mind, A person's heart and wearing a veil make a woman feel safe and comfortable when leaving the house.

From the brief description above, it can be underlined that the perspective of hate crime is usually used to analyze physical crimes that are based on hatred, prejudice, or suspicion. However, in this study, the perspective of hate crime will be used to analyze newsmaking about veiled women, where the news contains elements of prejudice, suspicion, and even hatred of veiled women. Researchers assume such news stories can foster hatred in the community, and then encourage them to take physical actions that are detrimental to veiled women. At least the community will be encouraged to commit acts of discrimination and intimidation against veiled women, in the form of exclusion, insults, or statements of hatred.

\section{RESEARCH METHOD}

This research is conducted with qualitative. As stated by Bogdan and Taylor (1975) quoted by Moleong (2007: 4) qualitative methodology is a research procedure that produces descriptive data in the form of written or oral words from people and observable behavior. In qualitative research methodologies, there are various methods of collecting data/sources that are commonly used. Jamesh Mc. Millan and Sally Schumacer in Research in Education; A Conceptual Introduction, there are at least four data collection strategies with multi-methods in qualitative research, namely participatory observation, in-depth interviews, study of documents and artifacts, and complementary techniques. On this occasion, what will be discussed further is about data collection strategies through documentary methods.

According to Burhan Bungin (2007: 121) "The documentary method is one of the data collection methods used in social research methodologies to trace historical data". While Sugiyono (2007: 329) states that the document is a record of events that have passed in the form of writing, pictures, or monumental works of someone ". The method or document study, although at first rarely considered in qualitative research methodologies, is now an important and inseparable part of qualitative research methodologies. This is caused by the awareness and new understanding that develops in researchers, that a lot of data is stored in the form of documents and artifacts. So that the extraction of data sources through document study is complementary to the qualitative research process. Even Guba as quoted by Bungin (2007) states that the level of credibility of a qualitative research result is more or less determined also by the use and use of existing documents.

Considering the above, the researcher tries to conduct a more in-depth study of veiled women's coverage to find out how the significance of the use and use of document studies in understanding mass media perceptions of veiled women with hate crime perspectives.

\section{RESULTS AND DISCUSSION}

Analysis the Newsmaking of Veiled Women and Terrorism 
After the capture of terrorism that occurred in Indonesia, the news in the mass media not only revealed the profile of a terrorist, but the mass media also featured the figures of the wives of the perpetrators who almost all used veils. As reported by the kompasian.com news portal, which wrote about the bombing of the JW Marriot and Ritz Carlton hotels some time ago by a group of terrorists under the command of Noordin M Top and his friends, the issue of wearing veils and veiled women is increasingly becoming a public concern. This is triggered by the fact that the majority of wives and families of suicide bombers and terrorists who have been masterminds of terror wear the veil. Like the wives of Noordin M Top who all wear the veil. as well as the wife of Saifuddin Zuhri, and many other wives of members of the terrorist who are currently being hunted by these 88 Police Headquarters. Until finally the veil stigma is always associated with the direction of hard-line thinking that has great potential as a group that supports acts of terrorism that occurred (www.kompasiana.com, 2009).

As a result, this kind of coverage also led to negative comments by the community that veiled women are the wives of bombers and advocates of terrorism. The image of women with a veil is getting worse, when the mass media reports that female corruptors also use the veil when facing court or investigators. Former Deputy Director of Permai Group Finance, Yulianis wore a veil that covered his face when examined during the trial of the alleged receipt of budgeting bribes from the Ministry of Youth and Sports and the Ministry of National Education with the defendant Angelina Sondakh in the Corruption Court. The black veil in a matching color with the robe worn by Yulianis had raised doubts about the defendant Angelina Sondakh. Not only Angelina, Nazaruddin had also objected because Yulianis was veiled when testifying during the trial of her case which took place in the Corruption Court some time ago (http://nasional.kompas.com, 2012).

The mass media views the use of veils by corruptors as mere camouflage to avoid being highlighted by the media and reporters. Reporting like this can bring up the interpretation that the veil and veil are tools to hide identity. News titled "Kehebohan" when a school in Tegal requires veils" (BBC Indonesia, 2017), opens the news with the phrase "When a conservative country like Saudi Arabia is determined to be more moderate and relax freedom for women, a school in Tegal imposes obligations veiled towards the students." The sentence wants to impress that the steps of the school management in Tegal is a setback that is contrary to the policies of the Government of Saudi Arabia, the country of origin of Islam. BBC Indonesia News also illustrates the excitement on social media related to the obligation to wear a veil at a school in Tegal. Followed later by informing education service officials to come and reprimand, and ordered the school to cancel the veil obligation. The school finally revoked the obligation to wear the veil in class. But after they finish studying, in the Islamic boarding school they must open the veil again.

The school is indeed part of Attholibiyah Islamic Boarding School. Since January 2017 all female students at the Attholibiyah Islamic Boarding School are required to wear a veil. According to BBC Indonesia, a number of students who had just entered the cottage in July 2017 were not accustomed to appearing without veils. Before entering the Attholibiyah boarding school, Sintia had never been veiled, despite being veiled. After graduating from junior high school in Brebes, he entered the Attholibiyah Islamic boarding school at the suggestion of his close relatives who routinely attended the Koran study there. In this pesantren he was required to wear a veil. At first he felt uncomfortable. "It was hot at first. Shortness. But in the following months I got used to it," he told BBC Indonesia reporters.

The article titled "The Mystery Behind the Veil" on kompasiana.com (2009) illustrates that veiled women cannot be accepted by society. It was stated in the article that the community has the view that veiled women are a group of people who are closed and rarely 
socialize in establishing relationships with the surrounding community. Veiled women tend to shut themselves down to interact with people who do not use the veil, in fact they are not wrong to wear the veil. But it is their exclusivity that drives the majority of the community to see them as a foreign group that is difficult to be invited to socialize. They are rarely seen socializing with their surroundings. There is hardly any friendship with community members who do not wear the veil. They really isolate themselves with the outside world except for certain interests such as shopping.

From the point of view of criminology, especially the theory of hate crime, veiled women realize that they are seen as terrorists or at least radical. Many stories that hurt the veiled women. At the beginning of meeting with veiled women there are those who show a negative assessment of veiled women, such as assuming a veiled woman resembles a ninja, feeling afraid when first meeting, associating with a bombing incident, and assuming a veiled woman is part of a particular community or sect. This confirms McPhail's explanation of hate crime. In his book, Hating Hate: Policy of Hate Crime Legislation (2000), Beverly S. McPhail explained that hate crime is a criminal behavior with biased motives. According to McPhail, the motive is bias that causes hate crime, because it is based on prejudice or suspicion. Prejudice is an attitude (usually negative) of a group towards other group members, based solely on membership in the group.

Various mass media express the opinions of veiled women about the tendencies of these communities. They said that the social prejudice that arose was because of the news about the Bali bombers who had veiled wives. So when you first meet the veiled woman associating it with terrorists. They also assume, the delivery of information through mass media such as radio, television, and others can influence the formation of an individual's prejudices. Could not help a number of veiled women feel shunned by other residents. Negative feelings that are owned by someone towards certain groups such as, when someone feels afraid and threatened with the existence of other groups around him. The results showed that some members of the community felt afraid when meeting veiled women, watched them and then left.

It is not too difficult to obtain community statements about their attitudes toward veiled women. Call it informant $\mathrm{A}$, when you first meet a veiled woman. Then informant $\mathrm{A}$ immediately left when he first met the veiled woman, because she felt afraid. This is consistent with the theory of hate crime that the indicator of negative prejudice is one of avoidance behavior. Individuals or groups who have prejudice will tend to avoid individuals or groups who are targeted by prejudice. The results also showed that the informant $\mathrm{B}$, when he first met with the veiled woman, informant B did not like it. Informant B lacked the initial sight of a veiled woman, because according to informant B in Islam there was no demand to cover her face. It confirms the hate crime assumption that prejudice is used to refer to many social groups that suffer losses, for example ethnic minority groups. Groups usually involve not only negative thoughts but also emotions such as anxiety, anger, revenge, animosity, or dislike.

The reporting of crime events in the mass media actually aims to carry out the crime control function. According to MacQuail (1992), as quoted by Barak, the first feature that can be attached to the media is the "function" (or hidden purpose) to ensure the continuity of social order, build public consensus on values, integrate activities, retain people and group in society. However, although the media has a role as an agent of social control, reporting a crime in the mass media is basically an interpretation, because journalists do not witness the event directly. As an interpretation, as a "reality" the news has been formed or constructed by its journalists, editors, and editor in chief. 


\section{CONCLUSIONS}

Berniqab or veiled, for the wearer is considered a demand of Islam that instructs Muslim women to cover genitalia from the view of men, niqab completely covers the body from top to toe. As in some Islamic countries, the hijab is known by several terms. If in Iran it is called chador, pardeh in India and Pakistan, milayat in Libya, abaya in Iraq, charshaf in Turkey, hijab in some Arab-African countries such as in Egypt, Sudan and Yemen. It's just a shift in the meaning of the hijab from the original meaning of the veil, changing the meaning of clothes to cover 40 female genitalia since the 4 th century H While in Riyadh, many women covered their faces from men with the niqab (veil) they used.

Legally there is actually no prohibition on using the veil, because that is the personal rights of the wearer. However, a series of terrorist acts involving female veiled elements, the community tends to be prejudiced negatively towards women who wear the veil. Even the mass media, especially in Indonesia, which should be proportional and neutral in reporting an event, also contributes to the image of veiled women by preaching sides that actually harm the veil users. This confirms the suggestion of Greek Barack (2009) about the tendency of the mass media to do mystification (obscurity of meaning), the mass media tends to create a "new reality" about crime that is not in accordance with reality. Regarding the crime, according to Barack, the reporting of reality, giving rise to certain interpretations and views among readers/audiences of the crime, both against the perpetrators and victims of crime.

\section{REFERENCES}

Arbani. 2012. Kejahatan Kebencian (Hate Crime) terhadap Transgender (Male to Female) dan Waria. Jakarta : Universitas Indonesia.

Barak, Gregg. 2009. Doing Newsmaking Criminology form within the Academy. Diakses dari: www.greggbarak.com.

Barka, Mokhtar Ben. 2006. Religion Fanaticm and Hate Crime in the United States. Revue Française d Etudes Américaines.

Bungin, M. Burhan. 2008. Penelitian Kualitatif: Komunikasi, Ekonomi, Kebijakan Publik, dan Ilmu Sosial Lainnya. Jakarta: Kencana.

Beverly A, McPhail. 2009. Hating Hate: Policy Implication of Hate Crime of Legislation. Polandia.

Furnivall, J.S. 1967. Netherlands India: A Study of Plural Economy. New York: Cambridge University Press.

Moleong, Lexy J. 2007. Metodologi Penelitian Kualitatif. Bandung: Remaja Rosda Karya.

Muthiah, M. 2013. Communication Dynamics of Vailed Arab Women. Jurnal Penelitian Komunikasi. BPPKI Bandung.

Rahman, Alif Fathur dan Muhammad Syafiq. 2017. Motivasi, Stigma dan Coping Stigma pada Perempuan Bercadar. Jurnal Psikologi Teori dan Terapan 2017, Vol. 7 No. 2.

Setyarini, Maya. 2018. Prasangka Sosial Civitas Akademika Terhadap Wanita Bercadar di Lingkungan Perguruan Tinggi Islam. Skripsi. Jurusan Psikologi Fakultas Psikologi. Universitas Muhammadiyah Surakarta.

Taura, Indra. 2016. Persepsi Masyarakat Tentang Perempuan Bercadar (Studi kasus Desa

To'bia Kabupaten Luwu). Jurnal Equilibrium FKIP Unismuh Makassar, Volume II No. 1. Januari. 